\title{
Landslide susceptibility and risk assessment in a non-mountainous region - a case study of Koronowo, northern Poland
}

\author{
Teresa MROZEK ${ }^{1}$, Izabela LASKOWICZ1 ${ }^{1}$ Lesław ZABUSKI², Marek KULCZYKOWSKI ${ }^{2, *}$ \\ and Waldemar ŚWIDZIŃSKI ${ }^{2}$ \\ 1 Polish Geological Institute-National Research Institute, Carpathian Branch, Skrzatów 1, 31-560 Kraków, Poland \\ 2 Polish Academy of Sciences, Institute of Hydro-Engineering, Kościerska 7, 80-328 Gdańsk, Poland
}

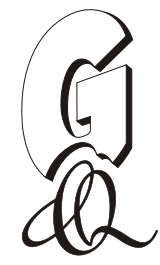

Mrozek, T., Laskowicz, I., Zabuski, L., Kulczykowski, M., Świdziński, W., 2016. Landslide susceptibility and risk assessment in a non-mountainous region - a case study of Koronowo, northern Poland. Geological Quarterly, 60 (3): 758-769, doi: 10.7306/gq. 1307

The study deals with landslide threats in a low-relief region which exemplifies an area rarely perceived as prone to such geohazards. Actually, in the gently undulated landscape in the vicinity of Koronowo at the Brda River (South Pomeranian Lake District, northern Poland) intensified landsliding was observed in the recent years. The field mapping and examination of air photos showed that endangered terrains are fairly extensive and cannot be limited to initially identified slope failure incidences (hot-spots). The devised landslide susceptibility and hazard map is an outcome of predictive modelling using empirical likelihood ratio function $(L R)$ with respect to seven evidential layers: elevation, slope angle, slope aspect, flow accumulation, surface deposits, depth to glacial raft, land cover as well as the landslide scars. The values of potential losses were calculated based on the mapped land-use categories and current market prices of estates and services. The final map, which resulted from combining landslide hazard with potential losses, shows damage propensity in a spatial scale of the town surroundings. It is meant as a supportive tool for decision-making with regard to allocating funds for stabilization measures or planning placement of new investments. On this background, stabilization solutions for selected sites are assessed in a cost-benefit context.

Key words: landslide hazard, risk evaluation, non-mountainous landscape, land-use plans, Brda valley.

\section{INTRODUCTION}

Landslides are common forms of natural hazard that result in significant losses and socio-economic consequences. They are mainly perceived as geohazards typical of mountainous or fore-mountainous terrains, that is well-documented by a vast literature (e.g., Brabb et al., 1972; Brabb, 1984; Carrara et al., 1991; Guzzetti et al., 1999, 2005; Pasuto and Soldati, 1999; Raetzo et al., 2002; Crozier, 2005; Lee et al., 2007; Thiery et al., 2007). Poland does not diverge from this pattern. Areas of high relief, mainly the Carpathians and their foreland (e.g., Bober, 1984; Zabuski et al., 1999; Margielewski, 2006; Wójcik at al., 2006) and, to a lesser degree, the Sudetes (e.g., Migoń et al., 2010) are commonly considered to have serious landslide problems. Yet in other regions, slope failures attracted less attention. Actually, landslides can be observed even in lowlands, lake districts or coastal regions where both substrate deposits (e.g., clays and loams of glacial deposition) and morphologic

\footnotetext{
* Corresponding author, e-mail: marek@ibwpan.gda.pl
}

Received: September 3, 2015; accepted: May 7, 2016; first published online: August 22, 2016 features (e.g., seashore cliffs, erosional scarps, steep river banks) are failure controlling factors (e.g., Grześ et al., 1997; Ostaficzuk, 1999; Ilcewicz-Stefaniuk et al., 2007). Despite a smaller spatial extent, when compared to the mountainous terrains, landslides in lower relief regions cause also significant problems, especially if they occur in areas subjected to significant human impact, expressed by housing or expanded infrastructure network. Unfortunately, due to insufficient awareness, this geohazard is usually underestimated and, in consequence, past failures are scarcely documented by both cartographic and archival geologic-engineering documentaries.

The current Polish law requires a county authority (starosta) to consider landslides in local land-use plans. Sadly, legislative regulations refer only to an obligation of delineating landslide boundaries in such plans - the rules neither define how the data on past and current landslides are to be acquired nor how they have to be integrated for implementation to territorial planning nor suitably used in building permission procedures. The same applies to areas likely apt to future (potential) mass movements. In effect, the imposed commitment is difficult to fulfil.

Typical sources of homogeneous landslide data available for the entire Polish territory are geologic maps at a scale of $1: 50,000$. Regrettably, the scale of the geologic maps is many times smaller than that of land-use plans which usually are to be prepared at a scale of 1:1,000. Moreover, the geologic maps were devised in most cases in the mid-20th century, thus, they 
are often outdated with regard to landsliding which was particularly intensive in Poland by the end of the 20th century and in the beginning of the 21st century (e.g., in 1997 or 2010). Additional sources of landslide data are archival land-use plans containing heterogeneous information about landslides and endangered areas that were delineated, almost exclusively, based on a slope inclination as the only criterion. In effect, the available data are often inconsistent and vague for rational planning needs.

General awareness of landslide hazard in many low-relief regions is inadequate, so natural slope failures are treated as individual incidences which might require only remedial measures, but are not considered in a context of landslide susceptibility in a broader (municipal or regional) scale. A good example is Koronowo, a historical, small town at the Brda River with interesting architecture and touristic-recreational assets. Here, landslides had damaged municipal infrastructure in several sites as reported by local administrative bodies. In the Brda River valley near Koronowo, intensified mass movements were observed in the 1970s and 1990s, and recently at the beginning of the 21st century. Example landslide failure is shown in Figure 1. Owing to specific land topography (such as moraine hills, steep-sided Brda valley, numerous erosional incisions) and substrate deposits (moraine loams, clay or mud inter-layered with fluvioglacial sands), landslide proneness seems apparent to professionals, but it is much less evident to decision-makers or residents.

For Koronowo, the nationally funded landslide project was launched, in which examination of singular damaging landslides (hot-spots) stimulated evaluation of landslide hazard and associated risk for a study area along the Brda River. That, in turn, was meant as a background for strategy on remedial priorities in the framework of cost-benefit analysis and for reasonable land management intended to minimise negative landslide consequences in the future.

The paper focuses on the issues related to the risk concept of Varnes (1984) that links landslide hazard with destructive consequences. The key tasks were to evaluate landslide susceptibility, indicate hazard and assess potential financial losses in the studied region. With the example of the Koronowo surroundings the problems encountered when evaluating landslide risk in a non-mountainous data-scarce region are shown. Questions related to economically sound remedial measures which arouse from this study are briefed for two hot-spots.

\section{STUDY AREA}

Koronowo is a small town (population of ca. 10.8 thousands) at the Brda River, ca. $20 \mathrm{~km} \mathrm{NW}$ of Bydgoszcz in a macro-region of the South Pomeranian Lake District (Fig. 2) (Kondracki, 2002). In this macro-region, a direct neighbourhood of Koronowo (Krajeńskie Lake District) occupies a boundary zone between the moraine upland and the Brda valley that formed in effect of fluvioglacial erosional processes. The Brda River flows generally southward, forming an arcuate bend that surrounds Koronowo from the west. The study area (ca. $14 \mathrm{~km}^{2}$ ) extends to the west and east of the valley. In this gently undulated landscape, the highest elevations exceed $105 \mathrm{~m}$ a.s.I. In the central part of the study area, local elevation of the western slopes reach up to $47 \mathrm{~m}$ above the valley bottom. The elevations descend northward and southward. Eastern slopes are lower and do not exceed $30 \mathrm{~m}$ in the villages of Samociążek or $20 \mathrm{~m}$ of Pieczyska. Relief of the western valley-side of the Brda River is significantly remodelled by mass movements.

The forested land occupies ca. $12 \%$ of the study area, bushes (14\%) often overgrow the Brda scarp, and farmlands $(43 \%)$ extend in the north, west and south. The centrally located town of Koronowo forms a compact built-up complex, comprising low-rise and multi-storey residential blocks, parks, and areas of public utility. The Brda bluffs within the town limits are built-up with low-rise residential houses or overgrown with forest or bushes. In rural terrains, adjacent to the town, low-rise detached or semi-detached residential houses, concentrating along transportation routes, occur side-by-side with farmlands.

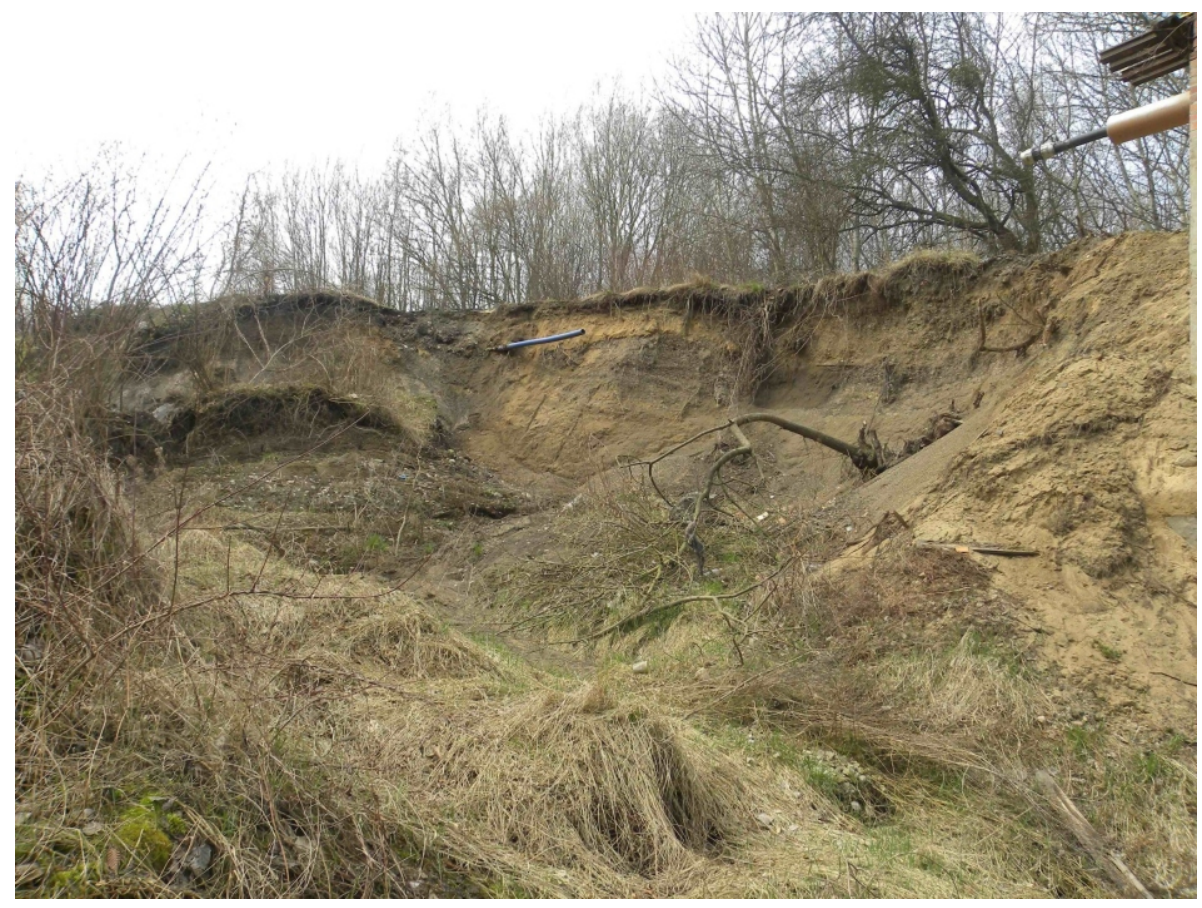

Fig. 1. Example landslide in Koronowo initiated in February 2011 (No. 16 - Table 1) 

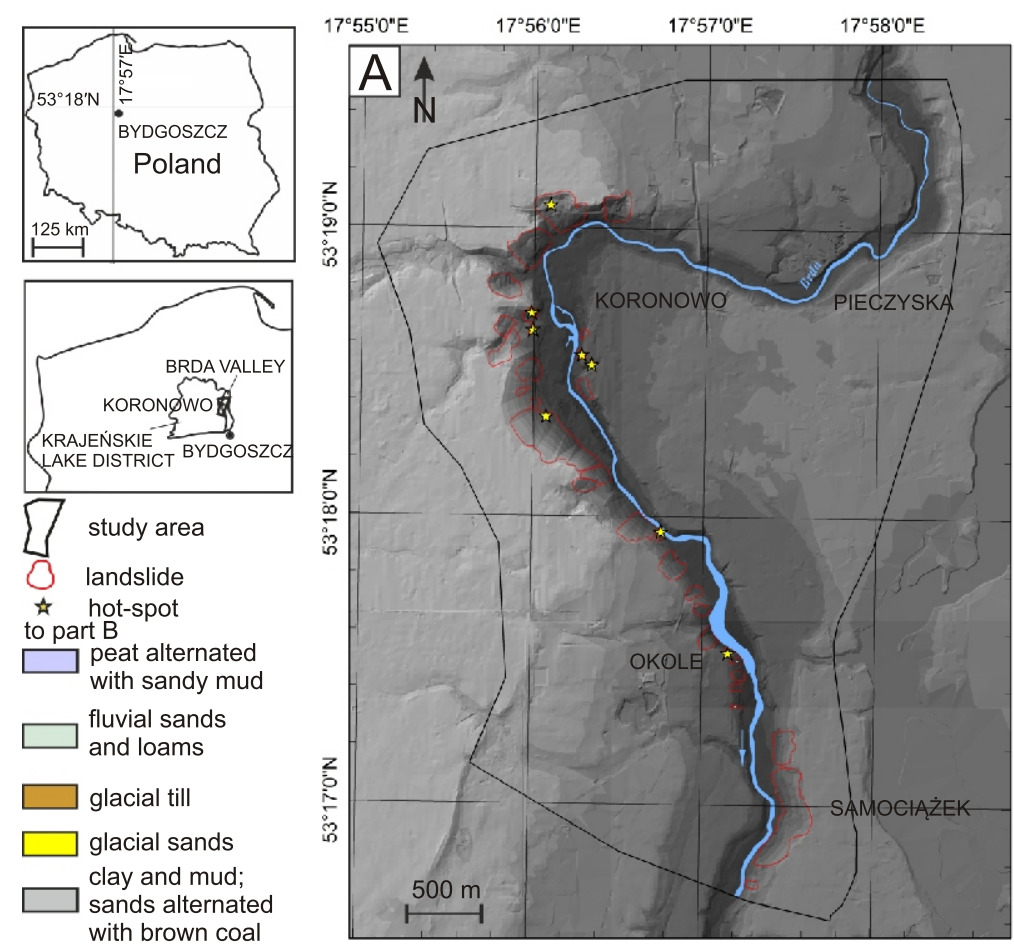

Fig. 2. Location of the study area on the background of DEM, landslide distribution (A) and compiled geology (B)

Out of the town, the Brda scarps are not used but the rural housing spreads to the upper verge of the scarp-faces.

The surroundings of Koronowo belong to the agro-climatic district with average annual precipitation exceeding 500-600 mm (Lorenc, 2005). Average annual precipitation increased from $554 \mathrm{~mm}$ in the period of 1955-1981 to $727 \mathrm{~mm}$ in the period of 2004-2011. Precipitation and meltwater are typical triggers of slope failures.

Considering the geologic setting, the study area is in the range of thick deposits related to the North Polish Glaciations. Fluvioglacial sands and gravels represent the Hrubieszów Interstadial, while the Main Stadial is represented by glacial till, fluvioglacial sands and gravel or glacilacustrine muds of the Leszno, Poznań and Pomeranian phases. Deposits of the Leszno Phase and fluvioglacial sands and gravels of the Pomeranian Phase are exposed in the eastern part of Koronowo. In the western part, glacial tills of the Poznań Phase predominate at the surface. The bottom of the Brda valley is filled with fluvial sands of flood and overflood terraces, while bottoms of smaller stream valleys are filled with sandy slack-water deposits. Accumulations of peat were found in local depressions (Fig. 2).

In places, glacial raft comprising sands, muds and brown coals either of Miocene or Pliocene age, were identified among the Quaternary deposits. The thicknesses of the complexes varied from 2 to $30 \mathrm{~m}$. Such complexes were found in deep boreholes in Koronowo, and in the nearby villages of Okole and Pieczyska (Listkowska, 1988) as well as in shallower boreholes drilled for this study. The top of the complex of clays and muds intercalated with brown coal occurs at depths ranging from $1.6-16 \mathrm{~m}$ in the northern part of the study area to $35.5 \mathrm{~m}$ in the village of Samociążek (western part of the study area). Here, ca. $25 \%$ of the area with a slope gradient exceeding $5^{\circ}$ are covered to a large extent with colluvial material, so that the Brda valley-sides are apparently apt to mass movements. At present, increasing human impact, associated with urbanization, is also an important factor which might lead to slope instability.

\section{LANDSLIDES INVENTORY}

In each landslide hazard or risk study a landslide inventory is a crucial component and should be as complete as possible in both space and time (Lang et al., 1999; van Westen et al., 2008). In case of this study area, the landslide inventory was an outcome of combining air photo analysis and field surveying. Starting from the landslides reported by the local authorities and being hot-spots due to their devastative consequences, 32 landslides were identified all together. The inventory, apart from mapping boundaries of the landslides, resulted also in surveying the characteristic morphological features such as main and minor scarps, transverse ridges, and bulges. Table 1 contains a list of all the registered landslides, including the most critical ones (hot-spots) marked in bold, while landslide locations are shown in Figure 2.

Based on interpretation of five series of air photos (of the years 1964, 1975, 1985, 1996 and 2004), an assessment of activity and timing of the landslides was attempted (Fig. 3 and Table 1). Complementary information about the activity was acquired by field checking and, sometimes, by interviewing local residents. In this way, for example, information about the landslide at the Brda valley bluff in Okole village, or about the landslides set in motion at the historical railway bridge at the turn of 2010/2011 were acquired. The total landslide area is almost 59 ha, including 12 ha of active landslides (Table 1).

The inventoried landslides occurring on the western valley-side of the Brda River are generally larger. The area of the largest one amounts to ca. 11.3 ha. The landslides located along the eastern side are less numerous and smaller - ranging from 0.06 to 2.5 ha, except for one which is over 10 ha.

In case of larger landslides developed on the valley-sides, their scarps reach an upper verge, while their toes override the youngest flood terraces of the Brda River. In fact, movement initiation takes place in the up-slope parts, although a very precise location of the displacement onset is not always possible. Water 
November + December total

$\stackrel{3,18,19,20}{\longrightarrow}$ active landslides (Table 1) (III, IV ... XII months - Roman numerals)

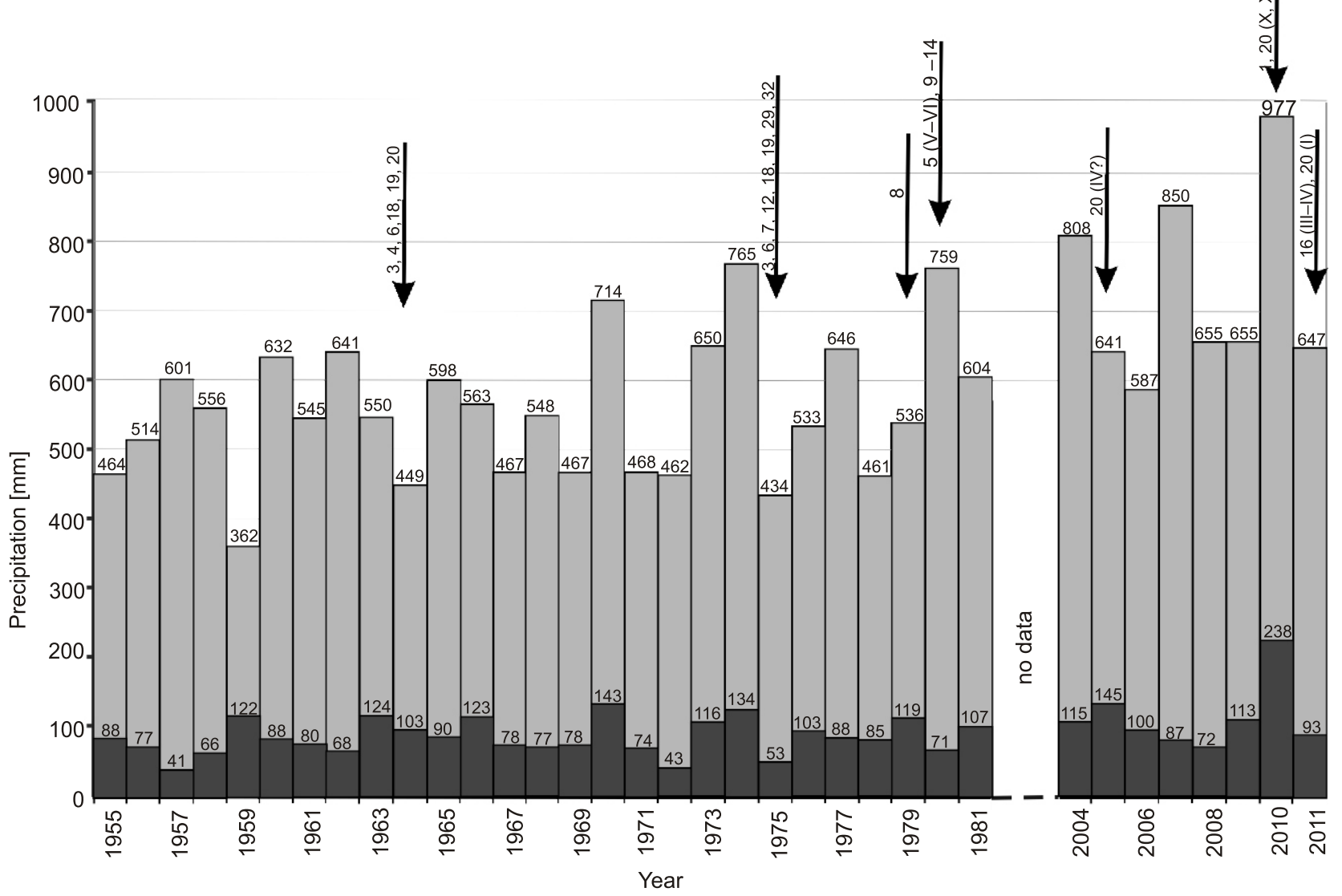

Fig. 3. Precipitation distribution and landslide activity

infiltrating into cracks weakens ground, increases pore-pressure and, due to exceeded breaking strength, makes a driving force to lead to instability. In upper parts of the landslides their failure surfaces have shapes similar to circular, while in the lower parts they are similar to linear. This is particularly well-visible in case of active landslides which have clear morphologic features.

The inventoried landslides have been classified following the combined schemes of Varnes (1978) and Cruden and Varnes (1996). In the study area, compound landslides (rotational-translational) predominate, some are classified as translational and only two are typical rotational ones.

The performed inventory of landslides in the study area has shown a difference between the number of damaging landslides (hot-spots) reported by the commune authority and the actually identified ones. Because of that a problem of assessing landslide hazard on the scale of the study area arises.

\section{LANDSLIDE SUSCEPTIBILITY AND HAZARD}

\section{METHOD OF ANALYSIS}

Evaluation of landslide hazard is based on a conceptual model which relates slope instability to causative (passive) fac- tors, typical of the study area, and triggering factors, which in the case of Koronowo is precipitation or/and meltwater. The taken conceptual approach is also based on the assumption that future landslides will have the same causal factors as the landslides initiated in the past (Chung and Fabbri, 2005).

The dataset used in the analysis consisted of inventoried landslides and environmental conditioning factors that were arranged as evidential maps or layers (Table 2) and, then, stored and managed using GIS software: Arclnfo v.9.2 (by ESRI, USA) and ILWIS v. 3.3. (by International Institute for Aerospace Survey and Earth Sciences in the Netherlands). The statistical analysis of landslide hazard was carried out using spatial prediction modelling packet SPMS v. 2.1 (by SpatialModels Inc., Canada).

To develop the predictive map, multivariate statistics was used following a step-wise strategy according to methodology described by Chung and Fabbri $(2003,2005)$ and Chung (2006). The performed spatial modelling is enrooted in a favourability function (FF) concept (Chung and Fabbri, 1993, 1999,2005 ) which links a landslide occurrence in a given cell (pixel) with occurrence of a multiple causative factors in the same cell. These factors form a dataset originating from $m=k+h$ evidence layers (maps) where $k$ denotes a number of categorized data (e.g., lithology, land cover), while $h$ is a number of continuous data layers (e.g., slope gradient, aspect). The method does not require continuous and categorized data 
T a b I e 1 For processing, the study area was subdivided into grid cells $(10 \times 10 \mathrm{~m})$ each of which has a pixel representation in an image file (the total of 141,620 pixels). The landslide layer was

Inventoried landslides

\begin{tabular}{|c|c|c|c|c|}
\hline $\begin{array}{c}\text { Land- } \\
\text { slide } \\
\text { no. }\end{array}$ & Occurrence region & $\begin{array}{l}\text { Instrumental } \\
\text { monitoring }\end{array}$ & $\begin{array}{c}\text { Area } \\
\text { (hectares) }\end{array}$ & Activity \\
\hline 1 & Tucholska & $\mathrm{X}$ & 2.69 & $\mathrm{~N}$ \\
\hline 2 & Tucholska & & 5.87 & $A, P, N$ \\
\hline 3 & Nakielska & & 4.40 & $\mathrm{~N}$ \\
\hline 4 & Nakielska & & 2.46 & $\mathrm{~A}, \mathrm{~N}$ \\
\hline 5 & Podgórna & & 0.65 & $\mathrm{P}$ \\
\hline 6 & Podgórna & & 1.15 & $\mathrm{~A}, \mathrm{~N}$ \\
\hline 7 & Podgórna & $x$ & 2.18 & $\mathrm{~A}$ \\
\hline 8 & Szańce & $x$ & 0.24 & A \\
\hline 9 & Grabina & & 1.77 & $\mathrm{~N}$ \\
\hline 10 & Grabina & & 0.26 & $\mathrm{P}$ \\
\hline 11 & Grabina & & 0.32 & $\mathrm{~N}$ \\
\hline 12 & Grabina & $x$ & 11.30 & $\mathrm{~A}, \mathrm{P}, \mathrm{N}$ \\
\hline 13 & Grabina & & 0.15 & A \\
\hline 14 & Grabina & & 1.07 & $\mathrm{~A}, \mathrm{~N}$ \\
\hline 15 & Wiadukt & & 3.01 & $\mathrm{P}$ \\
\hline 16 & $\begin{array}{c}\text { Most } \\
\text { (old railway bridge) }\end{array}$ & $x$ & 0.23 & A \\
\hline 17 & Okole & & 2.02 & $\mathrm{~N}$ \\
\hline 18 & Okole & & 0.69 & $\mathrm{~N}$ \\
\hline 19 & Okole & & 1.18 & $\mathrm{~N}$ \\
\hline 20 & Okole & $\mathrm{x}$ & 0.28 & $\mathrm{~A}$ \\
\hline 21 & Krzyżowa & & 0.27 & $\mathrm{P}$ \\
\hline 22 & $\begin{array}{l}\text { Cmentarz } \\
\text { (cemetery) }\end{array}$ & $x$ & 0.34 & $\mathrm{~N}$ \\
\hline 23 & $\begin{array}{l}\text { Cmentarz } \\
\text { (cemetery) }\end{array}$ & $x$ & 0.06 & $P$ \\
\hline 24 & Brzęczkowskiego & & 0.88 & $\mathrm{P}$ \\
\hline 25 & Okole & & 0.34 & A \\
\hline 26 & Okole & & 0.41 & $\mathrm{P}$ \\
\hline 27 & Okole & & 0.30 & $\mathrm{P}$ \\
\hline 28 & Okole & & 0.14 & $\mathrm{P}$ \\
\hline 29 & Okole & & 0.66 & $\mathrm{~N}$ \\
\hline 30 & Samociążek & & 2.55 & $\mathrm{~N}$ \\
\hline 31 & Samociążek & & 10.70 & $\mathrm{~N}$ \\
\hline 32 & Samociążek & & 0.40 & $\mathrm{~N}$ \\
\hline
\end{tabular}

com digitized inventoried landslides (vector file) converted to a raster format with a $10 \mathrm{~m}$ grid cell. Each grid cell was assigned 1 if a landslide was present (so called - occurrences) and 0 if it was a landslide-free remaining part of the study area (so called - no-occurrences).

Geologic data, which originated from the standard geologic map of Poland, scale 1:50,000 - sheet Koronowo (Listkowska, 1986, 1988), were revised with more detailed engineering-geologic documentation and checked in the field, where appropriate. In this way a vector file representing surficial deposits (lithostratigraphic categories) was prepared, again at the scale of 1:10,000 (Fig. 2B). Based on the borehole logs a vector map depicting depths to the Neogene clay deposits (a potential sliding surface) was prepared and then used as another evidence layer (glacial raft).

Land-use data were compiled from planning documentations, topographic maps and air photo analysis. The land-cover map was devised with a subdivision into eight categories (Table 2). The developed vector map illustrates typical land covers (e.g., forests, farmland) and current built terrains, all being proxies for infiltration conditions. This map serves also for further analyses when elements exposed to landslide hazard are considered in risk evaluation.

As it was the case of the landslide layer, geologic and land-use datasets were converted from digital vector maps to a raster format with a $10 \mathrm{~m}$ grid spacing.

The data on topography (slope geometry) were derived form $25 \mathrm{~m}$ Digital Elevation Model (DEM) obtained from CODGiK (Central National Geodetic and Cartographic Inventory). ILWIS routine was used to generate elevation $10 \mathrm{~m}$ grid cells as well as for calculating derivative evidence layers of slope gradients, aspect values, and flow accumulation.

\section{RESULTANT LANDSLIDE PREDICTIVE MAP}

In a predictive landslide hazard zonation, calculations of empirical frequency distribution functions (EFD) are a mid-stage of the employed procedure. The EFDs of landslide occurrence and non-occurrences help to assess the contribution of individual evidence layers to modelling. The ratio of the two frequency distribution functions is defined as a likelihood ratio function $(L R)$. Figure 4 exemplifies two distinct EFDs and the corresponding likelihood ratio function for the slope angle. Its computed values of the multivariate frequency distributions are favourability estimates used then for predicting. The pixel with the highest score is considered to be the cell where landslides either have occurred or are most likely to occur (Chung, 2006; Dewitte et al., 2006).

For devising areas susceptible to landsliding in this study a number of strategies have been tested. First, simulations started with all evidential layers (Table 2) in reference to all 32 inventoried landslides (the entire disturbed areas - scars) and separately to the corresponding landslide scarps. The latter, as zones where slope failures are initiated, are usually considered to be tightly related to causative factors (Chung and Fabbri, 1993). From the experience with hot-spot landslides, the failures were usually onset in the upper portions of the landslides, yet exact location of initial cracks was dimmed, which made precise delineating of the scarp areas vague. On the other hand, a majority of landslides reveal slow displacements and resultant deformations occur also down the scarps. Thus, that simulation based on landslide scars is more advantageous, although

The analysis was carried out for the study area (ca. $14 \mathrm{~km}^{2}$ ) as delineated on the 1:10,000 topographic map (cf. Fig. 2A). 
Analysed data layers used as conditioning parameters in the modelling

\begin{tabular}{|c|c|c|c|c|}
\hline Variable & Unit & Type & Original data & Description \\
\hline Elevation & $\mathrm{m}$ & $C^{*}$ & DEM & Elevation a.s.I. \\
\hline Slope angle & degree & C & DEM & Slope gradient \\
\hline $\begin{array}{l}\text { Slope } \\
\text { aspect }\end{array}$ & degree & C & DEM & Slope direction (0-359.9 degrees measured clockwise from north) \\
\hline $\begin{array}{l}\text { Flow accu- } \\
\text { mulation }\end{array}$ & pixel & C & DEM & $\begin{array}{l}\text { Local flow concentration involving the surrounding } 8 \text { pixels - resulting values mea- } \\
\text { sure flow into and not out of a cell }\end{array}$ \\
\hline $\begin{array}{l}\text { Surface } \\
\text { deposits }\end{array}$ & category & $\mathrm{T}^{* *}$ & $\begin{array}{l}\text { Geologic map; } \\
\text { field checked }\end{array}$ & $\begin{array}{l}\text { Categories: } \\
\text { peat alternating with sandy mud; fluvial sands; loams with sand; sand and gravel } \\
\text { underlain with glacial till; sand and gravel underlain with clay and mud; sand and } \\
\text { gravel underlain with glacial till; glacial sands; glacial till; clay and mud; sands al- } \\
\text { ternating with brown coal }\end{array}$ \\
\hline $\begin{array}{l}\text { Depth to } \\
\text { glacial raft } \\
\text { (to imper- } \\
\text { meable } \\
\text { layer) }\end{array}$ & $\mathrm{m}$ & $\mathrm{T}$ & $\begin{array}{l}\text { Geologic docu- } \\
\text { mentaries; deri- } \\
\text { vate interval } \\
\quad \text { map }\end{array}$ & $\begin{array}{l}\text { Categories: } \\
\text { depth (0-34 m sliced in 1-m-intervals) }\end{array}$ \\
\hline Land cover & category & $\mathrm{T}$ & $\begin{array}{l}\text { Local land-use } \\
\text { plans, topo- } \\
\text { graphic maps; } \\
\text { air photos }\end{array}$ & $\begin{array}{l}\text { Categories: } \\
\text { forest; bush; meadows and grassland; farmland; compact built area (housing); } \\
\text { loose built area (low-rise residential and farm homesteads); transportation trails; } \\
\text { quarries }\end{array}$ \\
\hline
\end{tabular}

${ }^{*} \mathrm{C}$ - continuous data layer; ${ }^{* *} \mathrm{~T}-$ thematic data layer

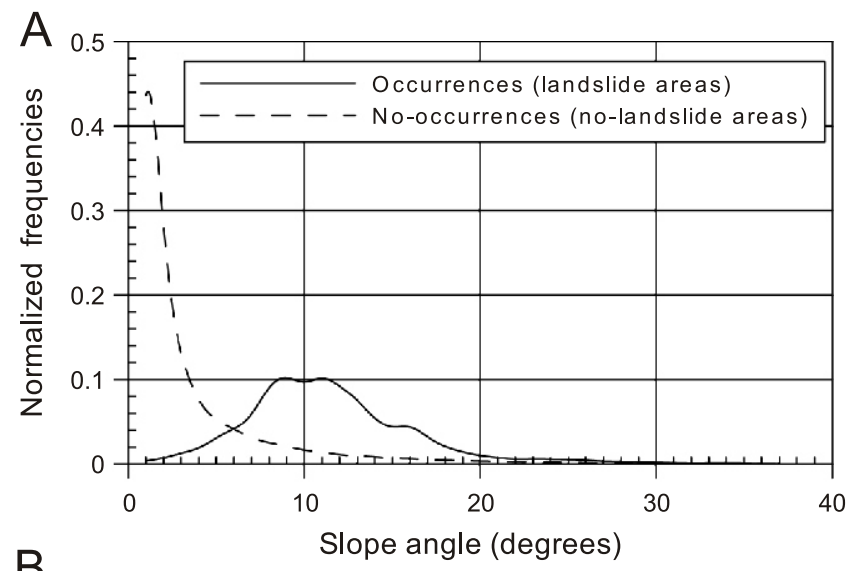

B

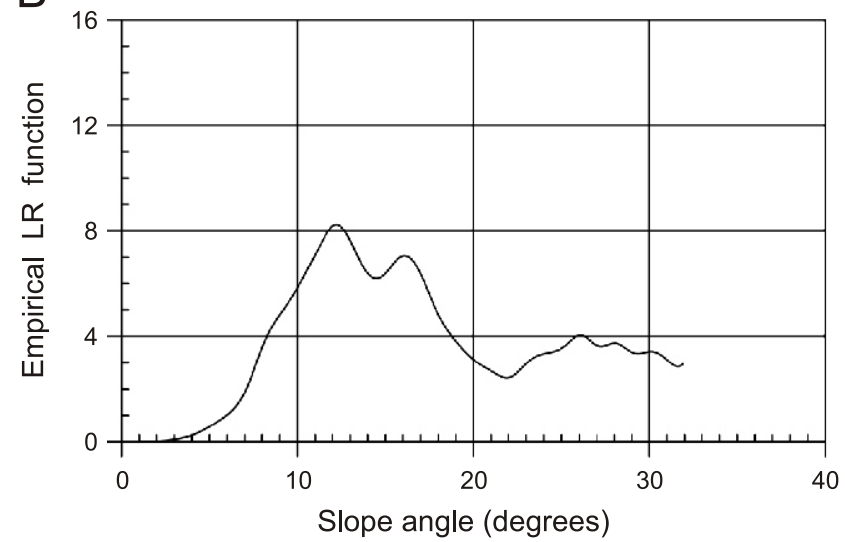

Fig. 4. Density distribution of landslide and non-landslide pixels for continuous (slope) data (A) and corresponding empirical likelihood ratio function (B) some "consequence pixels" might be included in the analysis. The adopted option was also substantiated by comparison of EDFs for scars and scarps. As the EDFs for lithological categories, slope inclination and flow accumulation were very much alike, the landslide hazard evaluating was confined to scars examination.

The likelihood ratio $(L R)$ function was estimated with regard to three thematic layers (surface deposits $G$, raft $R$, land-cover $L$ ), and four continuous evidence layers (elevation $E$, aspect $A$, slope S, focal flow F), i.e. GRL_EASF model. Figure 5 presents a monotonously increasing prediction rate-curve obtained for this model. For the GRL EASF model the highest hazardous $6 \%$ of the study area contain $62 \%$ of the predicted landslides.

According to the procedure used (Chung, 2006), the computed values of the $L R$ estimates (ranging from 0 to 1 ) for the total of 141,620 pixels were sorted in descending order, then ranked and standardized by the ranks, and next grouped into 200 classes, so that each class covered $0.5 \%$ of the entire study area. The class numbered 200 comprises pixels of the highest values, i.e. identifies $0.5 \%$ most hazardous (susceptible) area. A lower class number denotes lower hazard. The resultant landslide spatial hazard prediction map is presented in Figure 6.

As stressed by Chung and Fabbri $(2003,2005)$ cross-validation is a mandatory step in prediction modelling. In this study the landslides were partitioned into estimation and validation groups. Repeating calculations for each group, respectively, the prediction rate-curves were generated, which this time show the proportion of landslide of the validation group contained within the specified classes. These were used to interpret the original prediction map obtained based on all 32 landslides.

Then, to verify the robustness of the model with respect to geologic controlling factors, calculations were performed as follows. To test, for instance, the influence of the glacial raft evidence layer (i.e. underlying a less permeable stratum) on prediction results the modelling procedure was repeated excluding this dataset. The resultant prediction-rate curve was almost as steep as in the previous simulation, so the prediction power of the model was not drastically reduced. 


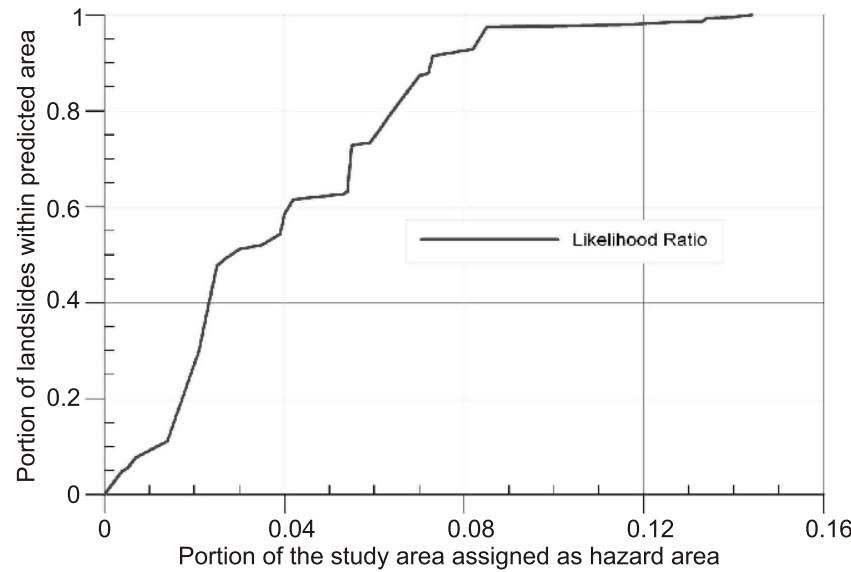

Fig. 5. Prediction rate curve for empirical likelihood ratio

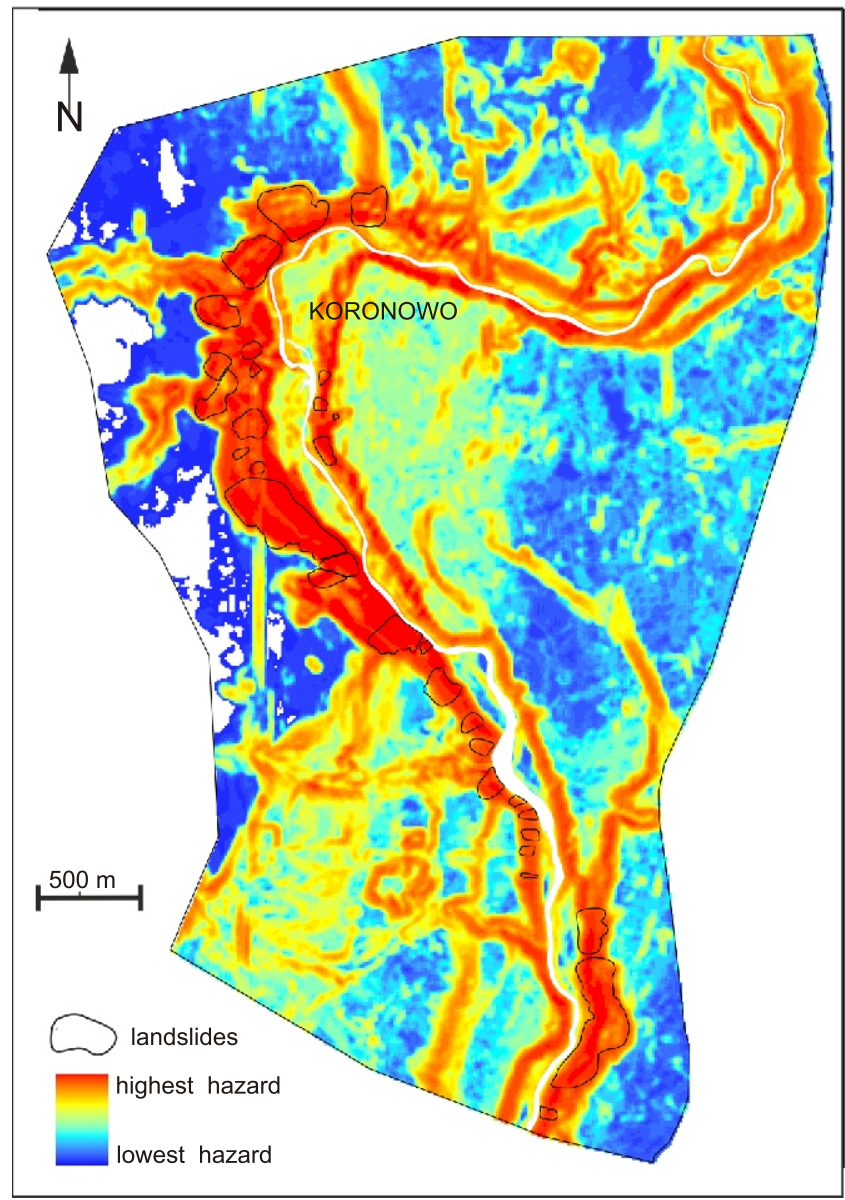

Fig. 6. Landslide spatial hazard prediction map of the study area based on 32 landslides and 7 layers using likelihood model. It was obtained by subdividing ranked values in 200 equally sized classes

Occurrence of future landslides in each pixel of a hazard class requires estimating the probability $P_{x}$. This probability is estimated using the equation proposed and discussed by Chung and Fabbri (2005) and Chung (2006):

$$
P_{x}=1-\left(1-p_{k}\right)^{\frac{n}{m}}
$$

where: $n$ - number of pixels in the future landslides (expected area of the future landslides); $m$ - number of pixels in the hazard class $\left(0.5 \%\right.$ of the study area), and $p_{k}-$ portion of landslides of the validation group in the hazard class obtained from the tabularized prediction rate-curve.

Such calculation, for time-based partitioning of past landslides, used to be performed for long-term scenarios (e.g., Chung and Fabbri, 2003; Davis et al., 2006; Dewitte et al., 2006) with an assumption that let say for $20-40$ year period causative factors and landslide occurrences (affected areas) represent average conditions.

Unfortunately, in the terrains which are perceived as non-apt to mass movement, hazard data on landslide timing and affected acreages are extremely rare. In many cases, revealing of past occurrences, even with a help of air photo interpretation, is also not very helpful especially in areas with a thick vegetation cover. This is the case of the Koronowo surroundings where morphologic features of past failures became blurred with time and could not have been identified reliably in many cases due to the resolution and scale of the air photos. The more reliable information refers only to the landslides triggered or reactivated in the recent five years. With this interlude, the landslide set was split into two exclusive time-based subsets for modelling.

As mentioned in section 3, the period of 2005-2011 was characterized by intensified precipitation that stimulated slope instabilities. In the study area, the activated landslides in this time span amounted to 12,533 pixels. For this dataset, it was possible to calculate probabilities, which were subsequently used to produce a map depicting landslide hazard in terms of probability. The derived map might seem ambiguous at a first glance. However, severe weather conditions (Bissolli et al., 2011) that resulted in floods and slope instabilities in the recent years in Eastern Europe point to a general propensity to climate amelioration. In this context, precipitation as high as that in the considered time interval, is believed to be an equally important landslide trigger also in a near future. For the presumed extreme conditions, the area subjected to future slope failures is likely to be similar to that of the studied period. Therefore, the obtained hazard map is found useful, as it can be supportive for territorial planners in framework of a "conservative" scenario.

\section{ELEMENTS AT RISK AND EVALUATION OF POTENTIAL LOSSES}

A partial or complete destruction of environmental assets and man-made developments is a consequence of landsliding processes. As damages to land or goods result in financial losses, elements at risk (i.e. those affected by hazard) also are defined in financial terms (Einstein, 1997). In other words, the elements at risk have to be assigned monetary values corresponding to funds needed for recovery after a damage has happened (Sterlacchini et al., 2007).

A way how financial values of the elements at risk are calculated depends mainly on the scale of a study. In any regional study, certain generalizations become obvious and unavoidable. Unfortunately, neither Polish public administration nor estate agencies possess detailed databases on financial values of land that might be used or treated as standards in a regional approach. Thus, evaluation of potential losses requires financial values to be estimated and assigned to singled-out land-use types on a case-by-case basis. 
Elements at risk, considered here, were classed in correspondence to categories depicted in the land cover map. Categories such as forests or farmland are fairly distinct units and can be valued relatively easy, whereas urbanized terrains are more challenging. The condensed built-up area of Koronowo is somewhat diversified as it comprises industrial terrains, low-rise and multi-storey residential blocks, parks, and areas of public utility (cemeteries) in the town limits. In rural terrains, adjacent to the town of Koronowo, there are also low-rise housing lots, which concentrate along transportation routes and occur side-by-side with agricultural terrains.

Linear features at risk considered in this study were limited to a transportation network. That of the town comprises motor-roads, railways and pedestrian trails (foot-routes). Currently, railways are not operating. Local roads are linked to the neighbouring national road no. 25 (Bydgoszcz-Toruń) via two streets which were set out in natural erosional incisions of the terrain. A former main road, running transversally on the western Brda scarp and a narrow-gauge railway route with a historical bridge over the river are important trails for pedestrians (foot commuters).

Based on the categories of the land-use map (Table 2), a derivative map of land values (Blöchl and Braun, 2005) for the entire study area was developed. Land values were evaluated for all land-use categories excluding water bodies (the Brda River). Prices (unit costs), given in Polish currency (PLN) per $1 \mathrm{~m}^{2}$, are presented in Table 3. In the case of forests, parks and farmland their costs were calculated based on average costs of such properties available on a real estate market. Owing to the scale of the study $(1: 10,000)$, for cost-evaluation purposes the built-up properties delineated on the land-use map were not treated separately as actual lots and buildings located on them. Instead, for lots and buildings the costs were aggregated and averaged, yielding the average cost of $1 \mathrm{~m}^{2}$ of the built-up terrain. In this way, the costs of the following land-use categories were evaluated: multi-storey housing lots, low-rise housing lots (including farm homesteads) and summer-residential lots, services or industrial properties, and land under agricultural-production. Costs of cemetery lots were evaluated as average tombstone costs, disregarding land prices based on data from burial companies. In the case of transportation routes the costs refer to constructing $1 \mathrm{~m}^{2}$ of a road, based on data from constructing companies and the national road directorate.

Land value was assessed based on prices of 2011. Because of large seasonal fluctuations and unstable real estate market, especially in recent years, land prices were converted to normalized values in a range of $0-1$ (Table 3 ). The normalized values illustrate relations between unit prices, and can be treated as universal measures with respect to fluctuating prices of real estates and services.

\section{LANDSLIDE RISK IN THE STUDY AREA}

Evaluation of landslide risk, as enrooted in Varnes's concept (1984), denotes coupling a landslide hazard with a consequence analysis. The consequences are determined by damages to elements at risk and to their vulnerability. Although vulnerability is an important component (e.g., Leone et al., 1996; Leroi, 1996; Dai et al., 2002; Alexander, 2005), it is very difficult to be precisely determined. Vulnerability relates a degree of damage to landslide hazard impact. Therefore, thorough records on intensity and types of destructions experienced by particular elements at risk are required if vulnerability is to be determined either quantitatively (e.g., Remondo et al., 2004, 2005) or in framework of semi-quantitative or qualitative codes (e.g., Leone et al., 1996; Alexander, 2005; Klimeš and Blahůt, 2012).

In opposite to other regions, where landslide-related damages usually have longer records, the non-mountainous Koronowo surroundings are lacking reliable historical evidences. However, real damages in the not-so-distant past (2005-2011) indicate that landslide consequences should be treated with a real precaution here. It substantiates considering a "conservative scenario", which assumes so severe destruction of goods and land that a recovery in a given location will not be possible (Blöchl and Braun, 2005). For such cases, vulnerability could be assigned 1 (Glade, 2003). It implies assuming a complete damage, so an owner will have no other choice than to leave his own property - in other words a purchase of a new property of similar standard will reflect owner's losses i.e. recovery costs. Thus, consequences (being a product of elements at

Land-use categories and their financial value

\begin{tabular}{|l|r|r|c|c|}
\hline \multicolumn{1}{|c|}{ Land use } & $\begin{array}{r}\text { Area } \\
{[\mathrm{ha}}\end{array}$ & $\begin{array}{r}\text { Area } \\
{[\%]}\end{array}$ & Unit cost (PLN/m² $)^{* * *}$ & Normalized unit cost \\
\hline Transportation trails & 67.3 & 5 & 138.5 & 0.10 \\
\hline Multi-storey housing & 46.9 & 3 & 1317.75 & 1.00 \\
\hline Low-rise housing & 212.1 & 15 & 437 & 0.33 \\
\hline Services & 23.0 & 2 & 1317.75 & 1.00 \\
\hline Industrial terrains & 95.1 & 7 & 68 & 0.05 \\
\hline Terrains of agricultural processing & 65.9 & 5 & 68 & 0.05 \\
\hline Farmland (arable fields) & 611.2 & 43 & 29 & 0.02 \\
\hline Summer residential area & 7.8 & 1 & 320 & 0.24 \\
\hline Forests and parks & 257.7 & 18 & 4.45 & below 0.02 \\
\hline Water bodies & 21.0 & 1 & - & - \\
\hline Cemeteries & 8.2 & 1 & 590 & 0.45 \\
\hline Total & 1416.2 & 100 & & \\
\hline
\end{tabular}

Costs as of September $2011^{* * *} 1 \mathrm{PLN} \approx 0.24$ Euro 
risk and vulnerability) will denote maximum potential losses expressed by costs of lost assets per unit area. Under such framing, the risk map depicts the possible highest financial losses. The highest risk is foreseen mainly along the steep western valley-sides of the Brda. Although it is the "worst case scenario" it points to a scale of an anticipated detriment which is important for financial planning tasks and for preventive actions or remedial measures to be undertaken.

The damage propensity can be analysed by overlapping elements at risk with landslide inventory or a landslide susceptibility map (Hufschmidt and Glade, 2010). In our study such an approach is visualized in Figure 7 by presenting the overlay of potential financial losses assigned to particular assets with the topmost classes of landslide hazard susceptibility $(A, B, C)$. This straightforward method is informative and appealing to decision makers. In the areas of the highest hazard, the most costly features (i.e. multi-storey housing) usually were not found, so presently risk is not so high. However, with an ever-growing human impact on new terrains, future losses might be much greater, thus such terrains require a certain code of practice with respect to their planned usage.

The landslides considered in this study as critical sites (eight hot-spots marked in bold in Table 1), if located on the western side of the Brda valley are generally contained within the higher hazard categories than those on the eastern side. In fact, landslides 12, 1 and 16 (Table 1) match with the most hazardous zone, while landslide No. 20 with the next less hazardous one. As these landslides demolished assets important for the commune, so they were subjected to more detailed investigations. Assessment of a rate and nature of deformations was possible owing to instrumental monitoring installed on these hot-spot landslides (Zabuski et al., 2015) and gave the base for finding an appropriate stabilising treatment. For sound risk reduction, feasibility of tasks addressed to particular hot-spots was assessed by comparison of costs $C$ denoting expenditures needed for remedial measures to benefits $B$ resulting from avoiding losses related to a potential slide. The treatment will be profitable if the $\mathrm{C} / \mathrm{B}$ ratio will be $<1$, i.e. the costs of countermeasures to be applied will be smaller than the expected direct and indirect losses in a given site. For instance, intended countermeasures to landslide no. 1 (Tucholska), which destructs the main road, are to comprise a drainage system. The countermeasures dedicated to landslide no. 20 (Okole), which generates threats to a house located close to a retrogressing head scarp, are to comprise artificial drainage and buttressing of the highest part in the region of the landslide crown (Fig. 8). The costs of the intended systems should counterbalance, in the first case, losses related to actual repairs of the road, its periodic closing and detours, while in the second case - the house value. The appropriate calculations were performed for all the hot-spots. As presented in Table 4, stabilization is not cost-effective only in the case of landslide No. 20. This substantiates the decision undertaken by local authorities on abandoning the site and relocating inhabitants.

\section{CLOSING REMARKS}

The surroundings of Koronowo was subjected to detailed examination due to observed ground deformations and a threat to infrastructure damage through mass movements, especially intensive in the last years. Observed landsliding was a cumulative effect of preconditioning and triggering factors. Among the former ones, slope gradient in a range of $10-20^{\circ}$ and the presence of Pliocene clays and muds or glacial till in the basement turned out to be the most decisive. Such lithological setting is

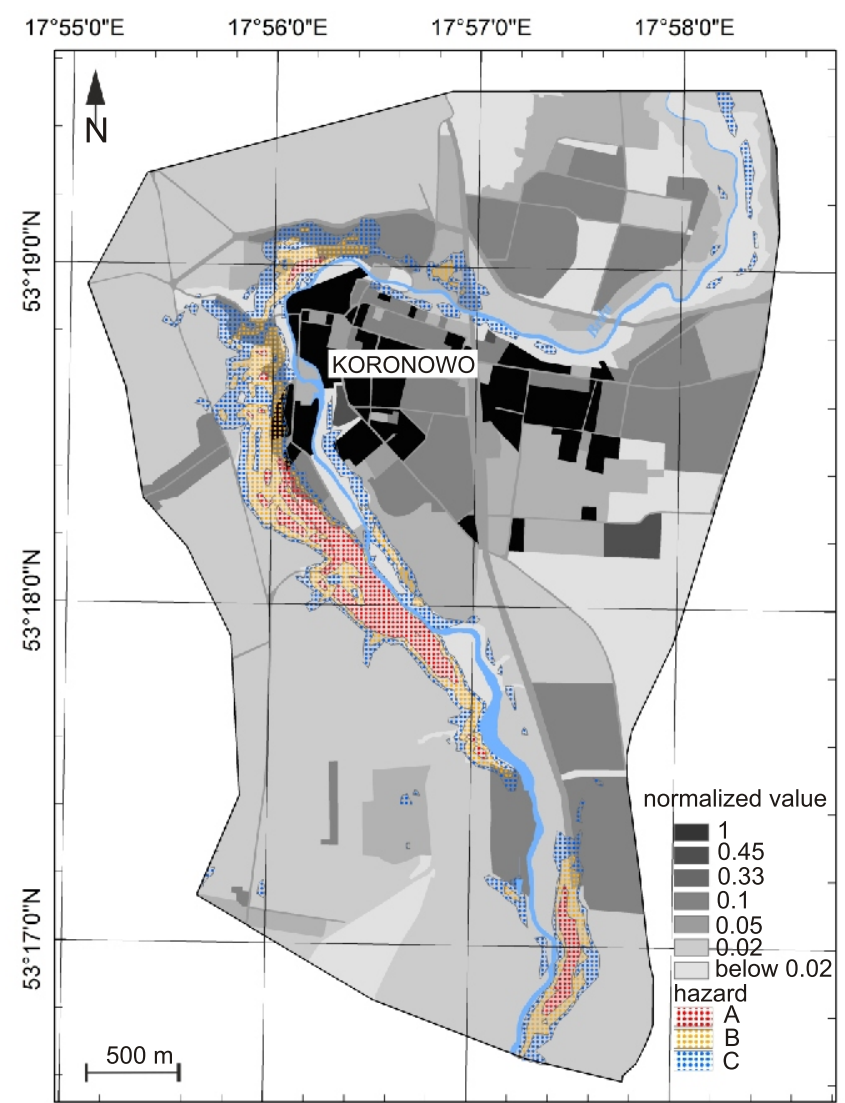

Fig. 7. Risk in the study area

Probability (in 5 years): $A-0.22-0.34 ; B-0.1-0.22 ; C-0.03-0.1$

not limited to the local scale of Koronowo surroundings, but is also a landslide-predisposing factor in other non-mountainous terrains, like for example those in northern Poland classed as moderately susceptible to mass movements (Van Den Eeckhaut et al., 2012). The failure triggers were related to rainand meltwater input, which are typical factors in other parts of the country as well (e.g., Gil et al., 2009).

With more landslides inventoried than initially (post-mortem) indicated, landslide-related hazard and risk in this non-mountainous region are not to be neglected. They have to

Table 4

Cost-benefit evaluation

\begin{tabular}{|l|r|c|c|}
\hline $\begin{array}{c}\text { Hot-spot landslides } \\
\text { (No., name) }\end{array}$ & $\begin{array}{c}\text { Benefit (B) } \\
\text { (PLN) }\end{array}$ & $\begin{array}{c}\text { Cost (C) } \\
\text { (PLN) }\end{array}$ & C/B \\
\hline 1 (Tucholska) & $5,108,218$ & 520,000 & 0.10 \\
\hline 12 (Grabina) & $2,153,310$ & 506,900 & 0.24 \\
\hline 7 (Podgórna) & $1,439,055$ & 35,700 & 0.03 \\
\hline 20 (Okole) & 206,508 & 289,500 & 1.40 \\
\hline 16 (Railway bridge) & 302,636 & 162,800 & 0.54 \\
\hline 22 (Cemetery) & 130,070 & 57,500 & 0.44 \\
\hline
\end{tabular}

C - costs denoting expenditures needed for remedial measures; B benefits resulting from avoiding losses related to a potential slide 


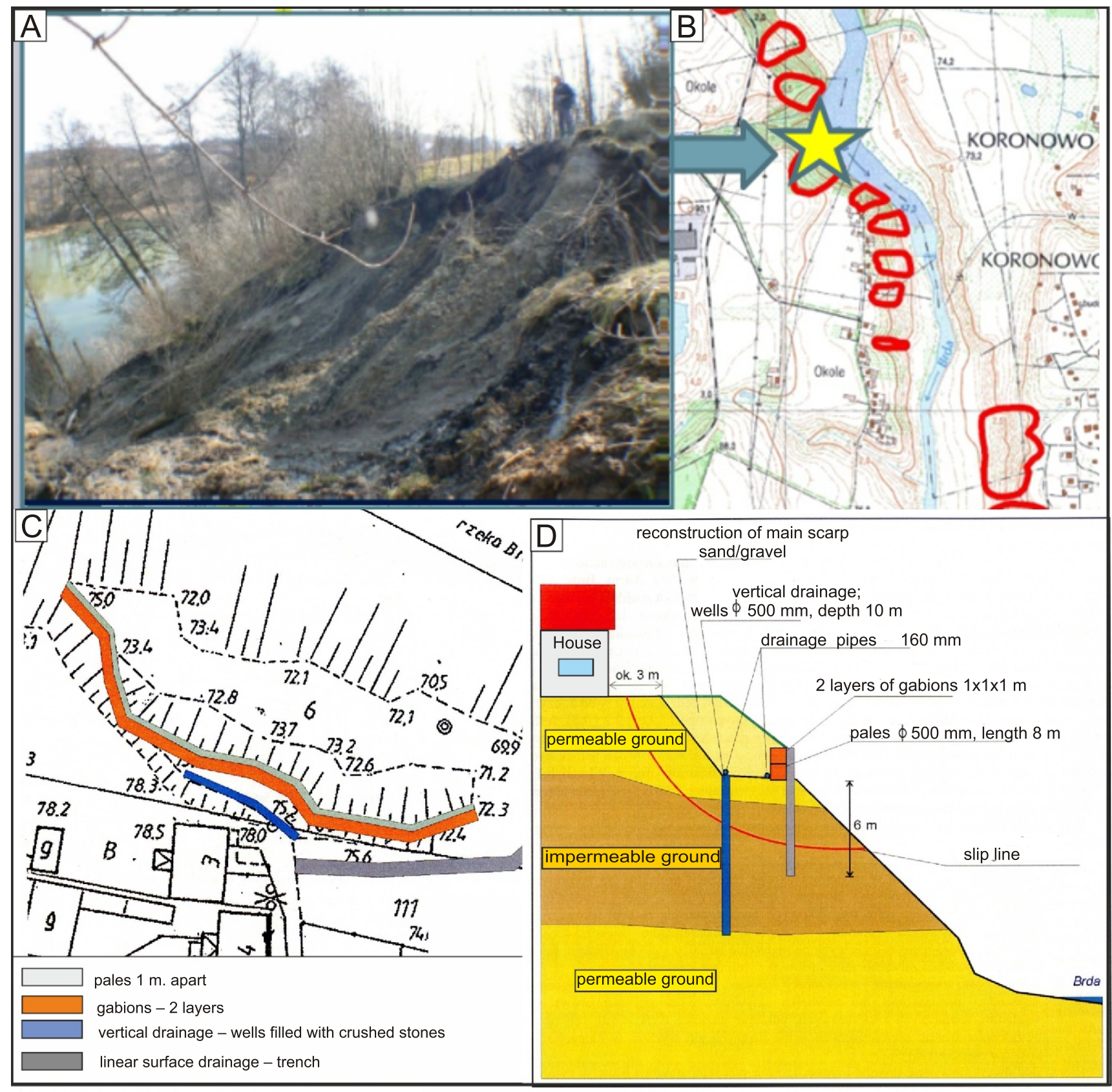

Fig. 8. Countermeasures for landslide no. 20 (Okole)

A - photo of the main scarp; $\mathbf{B}$ - location in the study area; $\mathbf{C}, \mathbf{D}$ - schemes of proposed stabilization measures

be treated not only as a site-specific problem, but as a crucial, spatially diverse issue.

Landslide inventory is a mandatory step, which provides accurate and current data needed for planning and building permit processes. Such inventory is also a starting point for mapping areas, where high damage due to intense mass movements are expected (Klimeš and Blahůt, 2012). Statistical modelling of landslide susceptibility and hazard, based on $L R$ functions and framed in the SPMS strategy, turned out to be effective in the Koronowo study area like in the other landslide data-scarce regions (Demoulin and Chung, 2007). The dataset used to achieve the above goal comprised typical information (DEM, lithological and land-use data) which can be fairly easy acquired in many regions. The satisfactory prediction results were obtained, even if only surficial deposits were considered. The latter can be derived easily from standard geologic maps, therefore, evaluation of landslide susceptibility might be performed for almost any area of interest (municipality). Unfortunately, certain limitations are related to the nature of the standard geologic maps as they provide mainly lithostratigraphic categorization of surficial deposits. Bearing in mind that the categories of such deposits are often the only proxy of geomechanical parameters of bedrock, which might be used for modelling purposes, the categories should be derived from the standard geologic maps very carefully. For reliable predictions, the lithostratigraphic divisions originating from the standard maps should be compiled to 
reflect a lithological character of the substratum rather than the age or origin, as well as to reduce the number of categories to a few ones necessary for modelling (Chung, 2006). In this field a close cooperation between experienced professional geologist and engineers is desired. So the assessment of terrains apt to landslide in non-mountainous region is a feasible task.

The performed study showed the implemented comprehensive approach. As singular landslide incidences indicated some threats, examination of a spatial context was done by assessing susceptibility and hazard in the scale of the municipality, then risk was evaluated to foster mitigation. In the case of low-relief regions such as Koronowo, the data on landslide timing and magnitude of events as well as on related extents of damages are rather scarce. Thus, one should remain conscious that probability calculations yielding the hazard map bear uncertainty related to a short time interval used for predictive purposes. Lack of a broad dataset necessary for reliable vulnerability estimation, led to consideration of the "worst case scenario" for risk estimation. Such scenario was found useful, as pointing to an upper limit of an anticipated detriments and fram- ing the expenditures to be considered in a commune budget. By indication of landslide susceptible areas and potential financial losses, a general awareness on landslide threats in the commune is improved. That helps decision makers to find the best management solutions and devise codes of practice, especially for intended new housing and transportation investments. In this way, non-structural measures are fostered in the risk management. Finally, the study showed that observed failures, named here hot-spots, were not accidental. Their locations could have been anticipated if the area were perceived as apt to landsliding. The countermeasures dedicated to those specific sites are backed by cost-benefit analysis. Such economic context helps local authorities and stakeholders to prioritise evidently costly structural measures.

Acknowledgements. The study was performed in framework of the national project No. 14-0008-06 funded by the NCBiR (National Centre for Research and Development). The authors are grateful to the anonymous reviewers for their constructive comments and suggestions.

\section{REFERENCES}

Alexander, D., 2005. Vulnerability to Landslides. In: Landslide Hazard and Risk (eds. T. Glade, M. Anderson and M. Crozier): 175-198. Wiley.

Bissolli, P., Friederich, K., Rapp, J., Ziese, M., 2011. Flooding in eastern central Europe in May 2010 - reasons, evolution and climatological assessment. Weather, 66: 147-153.

Blöchl, A, Braun, B., 2005. Economic assessment T of landslide risks in the Swabian Alb, Germany - research framework and first results of homeowners' and experts' surveys. Natural Hazards and Earth System Sciences, 5: 389-396.

Bober, L., 1984. Landslide regions in the Polish Flysch Carpathians and their relation to geologic setting of the region (in Polish with English summary). Biuletyn Instytutu Geologicznego, 340: 115-162.

Brabb, E.E., 1984. Innovative approaches to landslide hazard and risk mapping. Proceedings of the IV International Symposium on Landslides, Toronto, 1: 307-323.

Brabb, E.E., Pampeyan, E.H., Bonilla, M., 1972. Landslide susceptibility in San Mateo County, California, Miscellaneous Field Studies Map MF360 scale 1:62500, USGS, Reston, Va.

Carrara, A., Cardinali, M., Detto, R., Guzzetti ,F., Pasquid, V., Reinchenbach, P., 1991. GIS techniques and statistical models in evaluating landslide hazard. Earth Surface Processes and Landforms, 16: 427-445.

Chung, C.J., 2006. Using likelihood ratio functions for modeling the conditional probability of occurrence of future landslides for risk assessment. Computers and Geoscience, 32: 1052-1068.

Chung, C.J., Fabbri A.G., 1993. The representation of geoscience information for data integration. Nonrenewable Resources, 2: 122-139.

Chung, C.J, Fabbri, A.G., 1999. Probabilistic prediction models for landslide hazard mapping. Photogrammetric Engineering \& Remote Sensing, 65: 1389-1399.

Chung, C.J., Fabbri, A.G., 2003. Validation of spatial prediction models for landslide hazard mapping. Natural Hazards, 30 451-472.

Chung, C.J., Fabbri, A.G., 2005. Systematic procedures of landslide hazard mapping for risk assessment using spatial prediction models. In: Landslide Hazard and Risk (eds. T. Glade, M. Anderson and M. Crozier): 139-174. Wiley, Chichester.
Crozier, M.J., 2005. Multiple-occurrence regional landslide events in New Zealand: Hazard management issues. Landslides, 2: 247-256.

Cruden, D.M., Varnes, D.J., 1996. Landslides Types and Processes. In: Investigations and Mitigation, Landslides (eds. A.K. Turner and R. Schuster): 36-75. Transportation Research Board, NRC Washington DC Special Report, 247.

Dai, F.C., Lee, C.F., Ngai, Y.Y., 2002. Landslide risk assessment: an overview. Engineering Geology, 64: 65-87.

Davis, J.C., Chang, C.J., OhImacher, G.C., 2006. Two models for evaluating landslide hazards. Computers and Geosciences, 32: $1120-1127$.

Demoulin, A., Chung, C.J., 2007. Mapping landslide susceptibility from small datasets: A case study in the Pays de Herve (E Belgium). Geomorphology, 89: 391-404.

Dewitte, O., Chung, C.J., Demoulin, A., 2006. Reactivation hazard mapping for ancient landslides in West Belgium. Natural Hazards and Earth System Sciences, 6: 653-662.

Einstein, H.H., 1997. Landslide risk - systematic approaches to assessment and management. In: Landslide risk assessment, Proceedings of the International workshop on Landslide risk Assessment, 19-21 February, Honolulu (eds. D. Cruden and R. Fell): 25-50. Balkema, Rotterdam.

Gil, E., Zabuski, L., Mrozek, T., 2009. Hydrometeorological conditions and their relation to landslide processes in the Polish Flysch Carpathians (an example of Szymbark area). Studia Geomorphologica Caraptho-Balcanica, 43: 125-141.

Glade, T., 2003. Vulnerability assessment in landslide risk analysis. Die Erde, 134: 123-146.

Grześ, M., Rachocki, A., Rolka, A.M., 1997. Poland. In: Geomorphological hazards of Europe (eds. C. Embleton and C. Embleton-Hamann). Development in Earth Surfaces Processes, 5: 367-389.

Guzzetti, F., Carrara, A., Cardinali, M., Reichenbach, P., 1999 Landslide hazard evaluation: a review of current techniques and their application in multi-scale study, Central Italy. Geomorphology, 31: 181-216.

Guzzetti, F., Reichenbach, P., Cardinali, M., Galli, M., Ardizzone, F. 2005. Probabilistic landslide hazard assessment at the basin scale. Geomorphology, 72: 272-299. 
Hufschmidt, G., Glade, T., 2010. Vulnerability analysis in geomorphologic risk assessment. In: Geomorphological Hazards and Disaster Prevention (eds. I. Alcántara-Ayala and A Goudie): 233-234. Cambridge University Press, Cambridge.

Ilcewicz-Stefaniuk, D., Rybicki, S., Słomka, T., Stefaniuk, M. 2007. Mass movements in Poland - a review (in Polish with English summary). Geologos, 11: 365-373.

Klimeš, J., Blahůt, J., 2012. Landslide risk analysis and its application in regional planning: an example for the highlands of the Outer Western Carpathians, Czech Republic. Natural Hazards, 64: 1779-1803.

Kondracki J., 2002. Geografia regionalna Polski. Wydawnictwo Naukowe PWN, Warszawa.

Lang, A., Moya, J., Corominas, J., Schrott, L., Dikau, R., 1999. Classic and new dating methods for assessing the temporal occurrence of mass movements. Geomorphology, 30: 33-52.

Lee, S., Ryu, J.-H., Kim, L.-S., 2007. Landslide susceptibility analysis and its verification using likelihood ratio, logistic regression, and artificial neural network models: case study of Younging Korea. Landslides, 4: 327-338.

Leone, F., Asté, J.P., Leroi, E., 1996. Vulnerability assessment of elements exposed to mass-movement: working toward a better risk perception. In: Landslides, Glissements de terrain, Proceedings of 7 th International symposium on Landslides, Trondheim (ed. K. Senneset): 263-269. Balkema, Rotterdam.

Leroi, E., 1996. Landslide hazard - risk maps at different scales: objectives, tools and developments. In: Landslides, Glissements de terrain, Proceedings of 7th International Symposium on Landslides, Trondheim (ed. K. Senneset): 35-51. Balkema, Rotterdam.

Listkowska, H., 1986. Szczegółowa mapa geologiczna Polski w skali 1:50 000, arkusz Koronowo. Wyd. Geol., Warszawa.

Listkowska, H., 1988. Objaśnienia do szczegółowej mapy geologicznej Polski w skali 1:50 000, arkusz Koronowo. Wyd. Geol., Warszawa.

Lorenc, H., ed., 2005. Atlas klimatu Polski. IMGW, Warszawa.

Margielewski, W., 2006. Structural control and types of movements of rockmass in anisotropic rocks: case studies in the Polish Flysch Carpathians. Geomorphology, 77: 47-68.

Migoń, P., Pánek, T., Malik, I., Hradecký, J., Owczarek, P., Šilhán, K., 2010. Complex landslide terrain in the Kamienne Mountains Middle Sudetes, SW Poland. Geomorphology, 124: 200-214.

Ostaficzuk, S., 1999. Variety of landslides in Poland, and their possible dependence on neogeodynamics. In: Landslides, Proceedings of the Ninth International Conference and Field Trip on Landslides, 5-16 September 1999 (eds. J.S. Griffiths, M.R. Stokes and R.G. Thomas): 111-127. Bristol, U.K.

Pasuto, A., Soldati, M., 1999. The use of landslide units in geomorphological mapping: an example in the Italian Dolomites. Geomorphology, 30: 53-64.
Raetzo, H., Latelin, O., Bollinger, D., Tripet, J.P., 2002. Hazard assessment in Switzerland - Codes of Practice for mass movements. Bulletin of Engineering Geology and the Environment, 61: 263-268.

Remondo, J., Bonachea, J., Cendrero, A., 2004. Probabilistic landslide hazard and risk mapping on the basis of occurrence and damages in the recent past. In: Landslides: evaluation and stabilization, 1 (eds. W.A. Lacerda, M. Ehrlich, S.A.B. Fontoura and A.S.F. Sayăo): 125-130. Taylor \& Francis, London.

Remondo, J., Bonachea, J., Cendrero, A., 2005. A statistical approach to landslide risk modelling at basin scale: from landslide susceptibility to quantitative risk assessment. Landslides, 2: 231-328.

SPMS, 2006. Spatial Prediction Modeling System, Software v 2.0, User's Guide. SpatialModels Inc., Ottawa, Canada.

Sterlacchini, S., Frigerio, S., Giacomelli, P., Brambilla, M., 2007. Landslide risk analysis: a multi-disciplinary methodological approach. Natural Hazards and Earth System Sciences, 7: 657-675.

Thiery, Y., Malet, J-P., Sterlacchini, S., Puissant, A., Maquaire, O., 2007. Landslide susceptibility assessment by bivariate methods at large scales: application to a complex mountainous environment. Geomorphology, 92: 38-59.

Van Den Eeckhaut, M., Hervas, J., Jaedicke, C., Malet, J.P., Montanarella, L., Nadim, F., 2012. Statistical modelling of Europe-wide landslide susceptibility using limited landslide inventory data. Landslides, 9: 357-369.

Van Westen, C.J., Castellanos, E., Kuriakose, S.L., 2008. Spatial data for landslide susceptibility, hazard, and vulnerability assessment: an overview. Engineering Geology, 102: 112-131.

Varnes, D.J., 1978. Slope movement types and processes. Transportation Research Board, NRC Washington, D.C., Special Report, 176: 12-33.

Varnes, D.J., 1984. Landslide hazard zonation: a review of principles and practices. International Association of Engineering Geology, Commission on Landslides and Other Mass Movements on Slopes, UNESCO, Paris 3.

Wójcik, A., Mrozek, T., Granoszewski, W., 2006. Lithological conditioning of landslides and climatic changes with examples from the Beskidy Mts., Western Carpathians, Poland. Geografia Fisica e Dinamica Quaternaria, Special Issue, 29: 197-209.

Zabuski, L., Thiel, K., Bober, L., 1999. Landslides in flysch of the Polish Carpathians: Geology, modelling, stability calculations (in Polish). Wydawnictwo IBW PAN, Gdańsk.

Zabuski, L., Świdziński, W., Kulczykowski, M., Mrozek, T., Laskowicz, I., 2015. Monitoring of landslides in the Brda river valley in Koronowo (Polish Lowlands). Journal of Environmental Earth Sciences, 73: 8609-8619. 